\title{
Synergistic Effect of Flavonoids from Artocarpus heterophyllus Heartwoods on Anticancer Activity of Cisplatin Against H460 and MCF-7 Cell Lines
}

\author{
Nik Nurul Najihah Nik Mat Daud ${ }^{1}$, Abdi Wira Septama ${ }^{2, *}$, Nordin Simbak ${ }^{1, *}$, Nor Hidayah Abu Bakar ${ }^{1}$, \\ and Eldiza Puji Rahmi ${ }^{3}$ \\ ${ }^{1}$ Faculty of Medicine, Universiti Sultan Zainal Abidin, Jalan Sultan Mahmud 20400, Kuala Terengganu, Terengganu, Malaysia \\ ${ }^{2}$ Research Center for Chemistry, Indonesian Institute of Sciences, Kawasan PUSPIPTEK Serpong, Tangerang Selatan, \\ Banten 15314, Indonesia \\ ${ }^{3}$ Faculty of Medicine, UPN Veteran, Jl. Rs. Fatmawati, Pondok Labu, Jakarta Selatan, 12450, Indonesia
}

\begin{abstract}
Artocarpus heterophyllus has been used as traditional medicine. This plant is one of the sources of flavonoid. Flavonoid compounds possessed a wide range of biological properties including anticancer. This study was performed to investigate the cytotoxic effect of flavonoids from A. heterophyllus on H460 and MCF-7 cell lines. The interaction of flavonoids and cisplatin against tested cancer cells was also evaluated. MTT assay was used to determine the cytotoxic effect of flavonoid. Isobologram analysis was selected to evaluate the synergistic effect between flavonoid and cisplatin, their interaction was then confirmed using AO/PI staining method. Amongst of flavonoid compounds, artocarpin exhibited strong cytotoxic effect on both MCF-7 and H460 cell lines with $\mathrm{IC}_{50}$ values of $12.53 \mu \mathrm{g} / \mathrm{mL}(28.73 \mu \mathrm{M})$ and $9.77 \mu \mathrm{g} / \mathrm{mL}(22.40 \mu \mathrm{M})$, respectively. This compound enhanced anticancer activity of cisplatin against H460 and MCF-7. The combination produced a synergistic effect on H460 and MCF-7 cell lines with a combination index (CI) values of 0.2 and 0.18 , respectively. The AO/ PI stained demonstrated that the combination of artocarpin and cisplatin caused morphological changes that indicated apoptosis. Moreover, artocarpanone also significantly increased cytotoxic effect of cisplatin compared to its single concentration with CI below than 1 . This result suggested the potency of flavonoid named artocarpin to enhance the anticancer activity of cisplatin on H460 and MCF-7 cell lines.
\end{abstract}

Keywords - Artocarpus heterophyllus, artocarpin, non-small lung cancer cell, breast cancer cell, cytotoxicity, synergistic

\section{Introduction}

Lung cancer cells are the most common cancer in men, which is associated with tobacco smoking. It has been estimated that more than 1 million deaths per year all around the world due to this cancer. ${ }^{1}$ There are two broad histology types of lung cancer in which non-small cell lung cancer (NSCLC) accounts $85 \%$ of cases, while small cell lung cancer (SCLC) only causes $15 \% .^{2}$ On the other hand, breast cancer is still the most diagnosed cancer in women. Globally, it has been reported 1.3 million new

\footnotetext{
*Author for correspondence

Abdi Wira Septama, Research Center for Chemistry, Indonesian Institute of Sciences, Kawasan PUSPIPTEK Serpong, Tangerang Selatan, Banten 15314, Indonesia.

Tel: 021-7560929, Email: abdiwiraseptama@gmail.com

Nordin Simbak, Faculty of Medicine, Universiti Sultan Zainal Abidin, Jalan Sultan Mahmud 20400, Kuala Terengganu, Terengganu, Malaysia.

Tel/Fax 60-0109379287, Email: nordinsimbak@unisza.edu.my
}

cases with 0.5 million related deaths. This cancer can be identified according to the expression of specific cancer markers, such as oestrogen receptors (ER), Her2 oncogene, as well as progesterone receptor (PR). ${ }^{3}$ The use of chemotherapeutic agents and ionising radiation still become major options to eliminate tumour mass. There is evidence, however, that the combination of these therapies causes the incidence of tumor relapse that finally results in the development of drug resistance in cancer cells. ${ }^{4}$ Hence, it needs to find an alternative approach to reduce this limitation. Combination therapy using natural compounds as adjuvant in order to enhance the anticancer effect of commercial drug is one appealing strategy to overcome the resistance problem. The interaction between bioactive compounds and cytotoxic regiments may lead to the synergistic activity in targeted cancer cells.

In recent years, the use of herbal medicines based has become more popular and being accepted not only by local market, but also among western countries as it 
<smiles>COc1cc(O)c2c(c1)OC(c1ccc(O)cc1O)CC2=O</smiles>

1

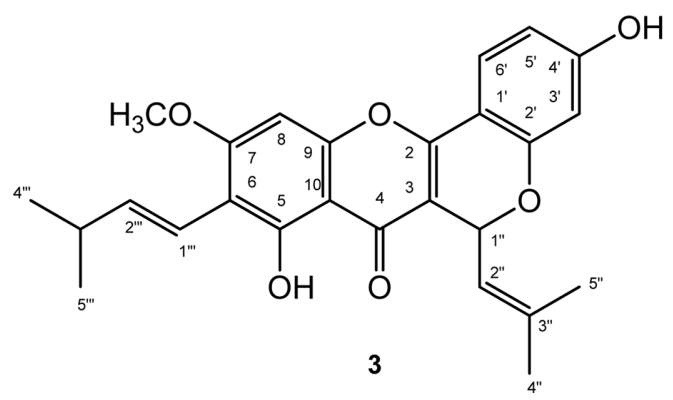<smiles>COc1cc2oc(-c3ccc(O)cc3O)c([CH+]C=C(C)F)c(=O)c2c(O)c1/C=C/C(F)F</smiles>

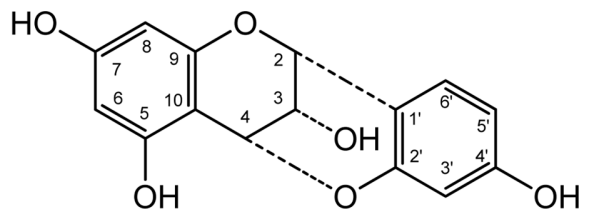

4

Fig. 1. Chemical structure of flavonoids isolated from A. heterophyllus heartwoods, artocarpanone (1), artocarpin (2), cycloartocarpin (3), and cyanomaclurin (4).

showed fewer side effects and safer compared to the modern treatment. ${ }^{5}$ Research studies have extensively focused on the antioxidant compounds of the natural product as it was revealed to possess antibacterial, antiinflammatory, anticancer, antiviral, anti-aging and other effects. ${ }^{6}$ Artocarpus heterophyllus has been used as a traditional medicine to treat several illnesses. ${ }^{7}$ This plant is known contained various of flavonoid compounds. ${ }^{8}$ According to previous studies, various flavonoids, compounds such as artocarpanone (1), artocarpin (2), cycloartocarpin (3), and cyanomaclurin (4) (Fig. 1) have been successfully isolated from this plan. ${ }^{9}$ These compounds possessed several pharmacological properties such as antibacterial, anticariogenic antioxidant, immunomodulator, and anti-tyrosinase. ${ }^{10-14}$ Although these compounds have been reported to have anticancer activity, however, there is no data available regarding their synergy effect in combination with commercial anticancer drugs. Therefore, the present study was undertaken to investigate the cytotoxic effect of flavonoid compounds as well as their synergistic effect when combined with commercial drugs.

\section{Experimental}

Chemical - Roswell Park Memorial Institute medium (RPMI-1640), Fetal Bovine Serum (FBS), PenicillinStreptomycin, 3-(4,5-dimetylthiazol-2-yl)-2,5-diphenyl tetrazolium bromide (MTT), and dimethylsulfoxide (DMSO), and cisplatin were purchased from Sigma Aldrich, St. Louis, MO. Artocarpanone, artocarpin, cycloartocarpin, and cyanomaclurin were isolated from Artocarpus heterophyllus heartwoods as previously described. ${ }^{7}$

Cell Culture - Human breast cancer MCF-7 cell line and non-small lung cancer H460 cell line (ATC.HTB177) was obtained from the American Type Culture Collection (ATCC) and cultured in complete medium containing RPMI-1640 media supplemented with $10 \% \mathrm{v} /$ $\mathrm{v}$ fetal bovine serum, and $1 \% \mathrm{v} / \mathrm{v}$ penicillin-streptomycin in $25 \mathrm{~cm}^{2}$ T-Flask (GIBCO, USA). The cells were humidified atmosphere with $5 \% \mathrm{CO}_{2}$ at $37^{\circ} \mathrm{C}$.

Cytotoxicity assay - Cytotoxic assay was performed according to Oladimenji et al. with slight modification. ${ }^{15}$ In brief, the cells $\left(5 \times 10^{3}\right.$ cells/well) were plated in a 96well plate and incubated for $24 \mathrm{~h}$. After incubation, five serial concentrations of compounds $(31.25,15.63,7.81$, $3.91,1.95 \mu \mathrm{g} / \mathrm{mL}$ ) were added into the plate and incubated for $72 \mathrm{~h}$ in $37^{\circ} \mathrm{C}$ at $5 \% \mathrm{CO}_{2}$. Cisplatin was used as positive control and untreated cell was used as a negative control. Next, $20 \mu \mathrm{L}$ of thiazolyl blue tetrazolium bromide (MTT) reagent $(5 \mathrm{mg} / \mathrm{mL})$ is added into each well, after $4 \mathrm{~h}$ incubation, $150 \mu \mathrm{L}$ of an absolute DMSO was added after aspiration of media. The cytotoxicity values were calculated after measuring the absorbance at $570 \mathrm{~nm}$ using a microplate reader. The experiment was repeated three times and the percentage of inhibition was calculated using the following formula: 


\section{Percentage inhibition $(\%)=$ \\ $\frac{(\text { Abs control }- \text { Abs treated })}{\text { Abs control }} \times 100 \%$}

Synergistic study - The interaction of flavonoid compounds with cisplatin was determined using an isobologram analysis as previously described with slight modification. ${ }^{16}$ Briefly, the dose-dependent effects of each compounds and fixed concentrations of compound were determined using MTT assay. The cells were then treated with a combination of flavonoid compounds and cisplatin. The combination index (CI) was calculated to the analysis of synergy, antagonism, and additive effect using the following formula:

$$
C I=\frac{(\mathrm{D}) 1}{(\mathrm{Da}) 1}+\frac{(\mathrm{D}) 2}{(\mathrm{Da}) 2}
$$

In which Da1 is the concentration of flavonoid compound required to produce certain percentage when used alone, D1 is the concentration of flavonoid which has the same percentage in combination with cisplatin. While, Da2 is the concentration of cisplatin required to produce certain percentage when used alone, D2 is the concentration of cisplatin which has the same percentage in combination with flavonoid. The CI values were defined as synergy if $\mathrm{CI}<1$, additive if $\mathrm{CI}=1$, and antagonist if $\mathrm{CI}>1 .{ }^{17}$

Morphological assessment of apoptosis using florescence microscope-The microscopic evaluation of morphological changes and apoptosis features of cells treated with flavonoid compound and cisplatin were visualized using this method. The method was conducted according to Goh et al., with slight modifications. ${ }^{18}$ Briefly, H460 cells and MCF-7 cells were seeded and treated with respective $\mathrm{IC}_{50}$ values. After 72 hours of incubation with the treatments, the growth medium was discarded. The cells were then stained with the dye mixture containing $10 \mu \mathrm{L}$ of $1 \mathrm{mg} / \mathrm{mL}$ acridine orange (AO) and $10 \mu \mathrm{L}$ of $1 \mathrm{mg} / \mathrm{mL}$ of propopidium iodode (PI). The stained cells were examined and observed using inverted fluorescence microscope.

Statistical analysis - All result values were expressed as the means \pm standard error of the mean (SEM) of triplicate experiments. The statistical significance of data within the treatment group was evaluated using the GraphPad Prism 6 software where a value of $p<0.05$ was considered as significant.

\section{Results and Discussion}

The cytotoxicity effect of flavonoid compounds against
Table 1. $\mathrm{IC}_{50}$ values of flavonoid compounds on $\mathrm{H} 460$ and MCF7 cancer cell lines

\begin{tabular}{lcc}
\hline \hline \multirow{2}{*}{ Compounds } & \multicolumn{2}{c}{$\mathrm{IC}_{50}(\mu \mathrm{g} / \mathrm{mL})$} \\
\cline { 2 - 3 } Artocarpanone & $\mathrm{H} 460$ & $\mathrm{MCF}-7$ \\
\multirow{2}{*}{ Artocarpin } & $(55.89 \mu \mathrm{M})$ & 23.34 \\
& 9.77 & $177.28 \mu \mathrm{M})$ \\
Cycloartocarpin & $(22.40 \mu \mathrm{M})$ & $(28.73 \mu \mathrm{M})$ \\
& 19.42 & 18.80 \\
Cyanomaclurin & $(44.74 \mu \mathrm{M})$ & $(43.31 \mu \mathrm{M})$ \\
& 15.84 & 20.54 \\
Cisplatin & $(55 \mu \mathrm{M})$ & $(71.31 \mu \mathrm{M})$ \\
& 12.96 & 10.29 \\
\end{tabular}

MCF-7 and H460 cell lines were determined using MTT assay. Amongst of testing compounds, artocarpin potentially induced highest cytotoxicity against both of MCF-7 and $\mathrm{H} 460$ cell line with $\mathrm{IC}_{50}$ values of $12.53 \mu \mathrm{g} / \mathrm{mL}(28.73$ $\mu \mathrm{M})$ and $9.77 \mu \mathrm{g} / \mathrm{mL}(22.40 \mu \mathrm{M})$, respectively (Table 1$)$. The result was confirmed by observing the treated cells under microscope in which treatment with artocarpin caused cells damaged after $72 \mathrm{~h}$ incubation. In contrast, other compounds named cycloartocarpin, artocarpanone, cyanomaclurin, dyhidromorin only displayed mild cytotoxicity effect against MCF-7 and H460 cell lines.

Artocarpin seemed to be the most potent compound against both MCF-7 and $\mathrm{H} 460$ cell lines. It was in agreement with previous studies, artocarpin exhibited strong cytotoxic effect against human T47D breast cancer cells. ${ }^{19}$ Moreover, this result was also consistent with another previous finding associated with artocarpin in which not only induced ROS generation but also causing DNA oxidative damage in tumour cells. ${ }^{20}$ Correspondingly, there is extensive evidence that revealed prenyl group plays a crucial role in deciphering the associated cytotoxic properties in flavonoid compound. The investigation of the structure-cytotoxic activity on MCF-7 and H460 cell lines using the isolated compounds demonstrated that the isoprenyl flavones structures along its joined position and numbers of flavonoids improved their cytotoxicity. ${ }^{21}$

The use of chemotherapeutic agents for cancer treatment still remains challenging, in particular their resistance problem. Cisplatin is the most common chemotherapy drug that has been used for the treatment of various type cancers including breast and lung cancer. However, cancer gradually raises resistance to cisplatin through several mechanisms such as increased inactivation of drugs, reduced intracellular accumulation, and gain DNA repair. ${ }^{22}$ The alternative strategy to overcome this problem is the use of drug in combination. The interaction of two 


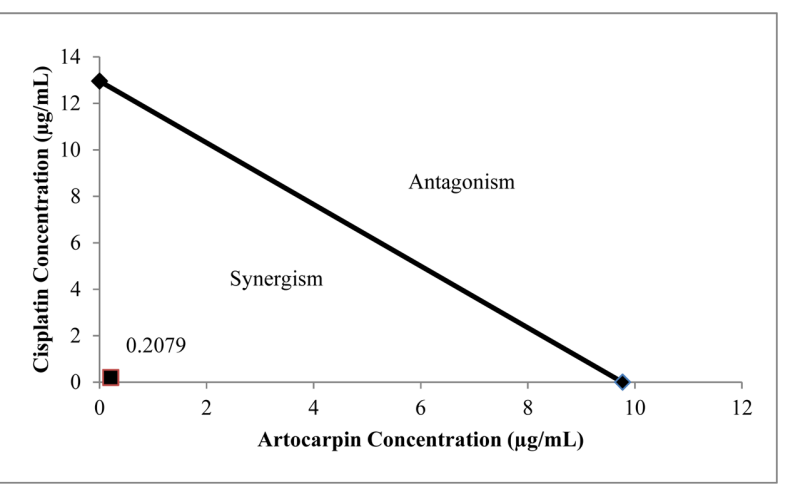

(a)

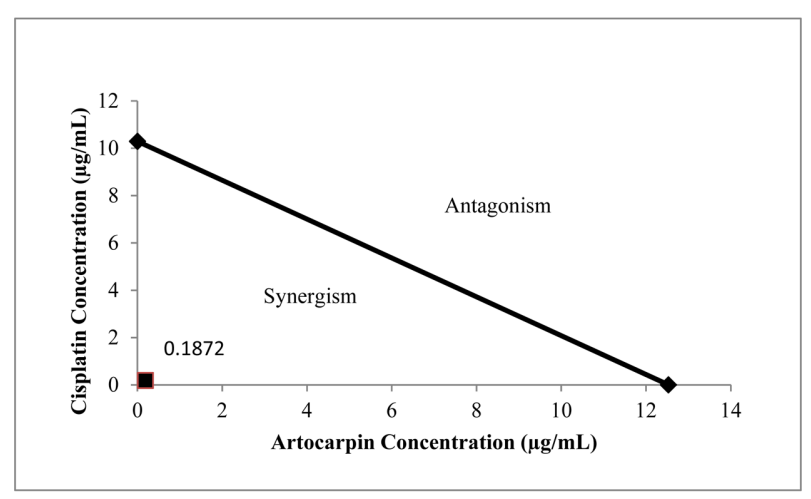

(b)

Fig. 2. Isobologram analysis of H460 (a) and MCF-7 (b) when treated with combination of artocarpin and cisplatin.

compounds in combination may enhance their activity. In case of synergy, different agents probably have different target of action and influence each site to achieve the same response. On the other hand, the different compounds may trigger the same site of action and it will generate agonistic activity. ${ }^{23}$

In this study, isobologram analysis was used to evaluate the interaction between flavonoid compounds and cisplatin. Artocarpin which exhibited strong cytotoxicity effect was selected to be combined with cisplatin in order to generate any synergistic effect against cancer cell lines. As displayed in Fig. 2, the $\mathrm{IC}_{50}$ value of artocarpin and cisplatin in combination was below the straight line. These results might indicate the synergistic interaction of flavonoid compound with cisplatin against $\mathrm{H} 460$ cells and MCF-7 cells. The CI was then analysed to verify the synergistic effect of flavonoid compound and cisplatin. Artocarpin in combination with cisplatin produced a synergistic effect in H460 cells and MCF-7 cells with CI values of 0.2 and 0.18 , respectively.

The synergistic effect of artocarpin with cisplatin against $\mathrm{H} 460$ and MCF-7 cell lines were then confirmed using fluorescence microscope. Morphological observation of apoptosis was assessed with dual-fluorescence for live or dead nucleated cell concentration in heterogeneous samples using acridine orange $(\mathrm{AO})$ and propidium iodide (PI). The orange $\mathrm{AO}$ and pink PI are the most used of nucleic acid binding dyes to measure the cell viability. ${ }^{24-26}$ This AO/PI staining method was performed to observe viable, necrotic, or apoptosis cells after treatment with compound in combination. $\mathrm{AO}$ is a cell membrane permeable dye that only binds to DNA and RNA in live cells via intercalation meanwhile PI is a membrane impermeable molecule that is capable of binding to DNA and RNA upon the loss of integrity of cellular membrane in dead cells. ${ }^{27}$ Hoechst/PI or 7AAD are also another fluorescence-based dyes that can be used to measure viability, however, AO/PI was selected due to their stability and popularity for image-based viability analysis.

The result showed that the treatment with combination of artocarpin and cisplatin, the number of $\mathrm{H} 460$ and MCF-7 cell lines were lower than treatment with single compound. However, the number of apoptotic cells after treated with compound in combination were significantly higher compared to single compound (Fig. 3). The morphological observation in the cell nuclei of H460 and MCF-7 cells for $72 \mathrm{~h}$ after treatment with combination of artocarpin and cisplatin showed significant morphological changes compared to untreated control. In AO/PI image analysis, AO-stained live cells and PI stained dead cells in green and red fluorescence channels were observed. The viable cells displayed a uniform green fluorescence with the appearance of a circular cell with an intact nucleus. Early apoptotic cells have green nuclei with chromatin condensation and membrane blebbing while late apoptotic cells have orange to the red nucleus with condensed or fragmented chromatin. Necrotic cells display a uniform orange to red nucleus with a condensed structure. ${ }^{28-29}$

The result has proved the potency of artocarpin, however, the interaction of this compound with commercial anticancer drugs; cisplatin needs to be explored more. Therefore, this study also focused on evaluation of synergistic effect of flavonoid compounds in enhancing the anticancer activity of cisplatin. In the present study, we found that artocarpin increase antitumor activity of cisplatin on H460 and MCF-7 cell lines. Furthermore, the combination of artocarpin and cisplatin increased the efficacy of each compound by producing a synergistic effect. This combination only required low concentration of each compound to achieve their cytotoxic effect on cancer cells. These results were then underlined using 
Artocarpin

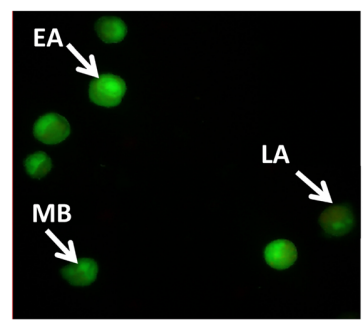

Artocarpin

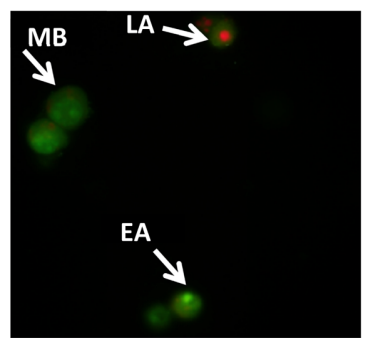

Artocarpin - Cisplatin
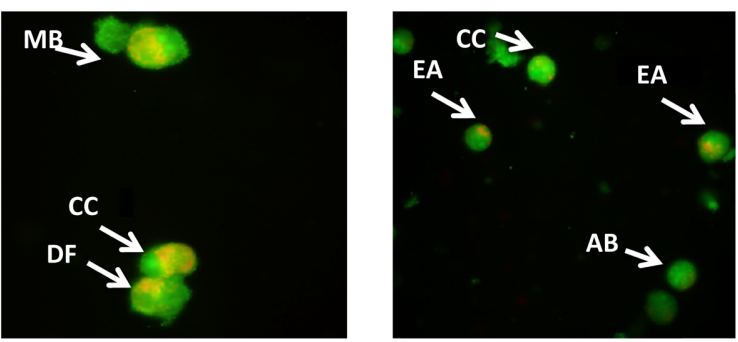

Control (untreated)

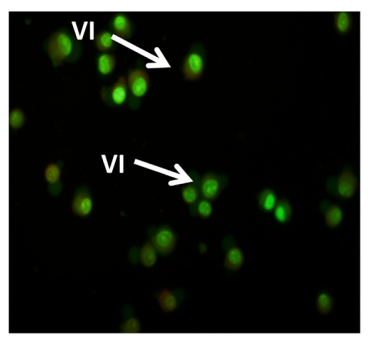

(b)
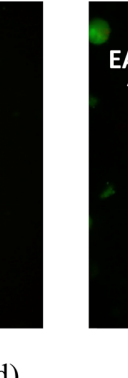

Artocarpin - Cisplatin
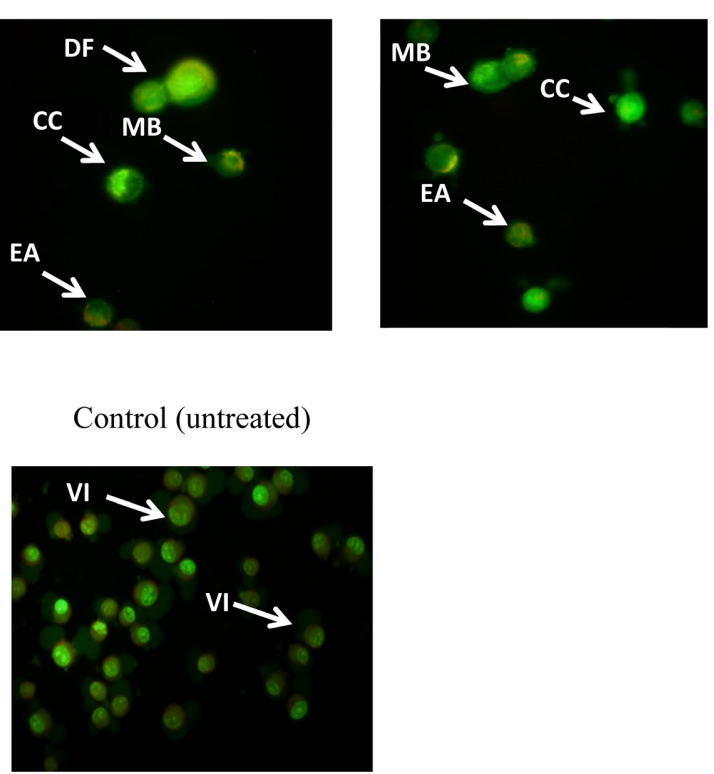

(a)

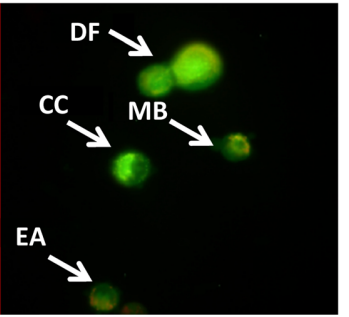

Control (untreated)

Cisplatin 
target cell lines. When used in combination, artocarpanone and cisplatin produced a synergistic effect. This combination also caused morphological changed on target cells and lead to apoptosis. These results indicated that a flavonoid compound may enhance cytotoxic effect of cisplatin to produce a synergistic effect. The finding was in agreement with previous studies, where it has been reported that deguelin, a flavonoid compound increase antitumor activity of cisplatin against gastric cancer cells. ${ }^{16}$ Furthermore, another study also reported that triptolide, a diterpene from Tripterygium wilfordii in combination with cisplatin produced a synergistic anticancer effect in gastric cancer cells. By this combination, triptolide increased apoptosis effect of cisplatin through activation of caspase3 and caspase- $9 .{ }^{30}$

In conclusion, artocarpin in combination with cisplatin displayed synergistic effects. These combinations produce significant anticancer activity in breast and non-small lung cancer cell lines. This finding suggests the potency of flavonoid compounds in enhancing anticancer activity of commercial drug named cisplatin. Nevertheless, further experiments are still required to elucidate their mechanism of action.

\section{Acknowledgments}

The authors would like to thank the Ministry of Education, Malaysia under the Fundamental Research Grant Scheme (FRGS 2017-2020) and Universiti Sultan Zainal Abidin (FRGS/1/2017/SKK06/UNISZA/03/1) for financial and technical supports.

\section{References}

(1) Torre, L. A.; Bray, F.; Siegel, R. L.; Ferlay, J.; Lortet-Tieulent, J.; Jemal, A. CA Cancer J. Clin. 2015, 65, 87-108.

(2) Oser, M. G.; Niederst, M. J.; Sequist, L. V.; Engelman, J. A. The Lancet Oncol. 2015, 16, e165-e172.

(3) Tao, Z.; Shi, A.; Lu, C.; Song, T.; Zhang, Z.; Zhao, J. Cell Biochem. Biophys. 2015, 72, 333-338.

(4) Borghei, Y. S.; Hosseini, M.; Dadmehr, M.; Hosseinkhani, S.; Ganjali, M. R.; Sheikhnejad, R. Anal. Chim. Acta. 2016, 904, 92-97.

(5) Ahmad, M.; Khan, M. A.; Marwat, K. S.; Zafar, M.; Khan, M. A.; Hassan, T. U.; Sultana, S. American-Eurasian J. Agric. Environ. Sci. 2009, 5, 126-140.

(6) Cai, Y.; Luo, Q.; Sun, M.; Corke, H. Life Sci. 2004, 74, 2157-2184.
(7) Salguero, C. P. A Thai herbal : traditional recipes for health and harmony; Findhorn press: Scotland, 2003, p 119.

(8) Arung, E. T.; Yoshikawa, K.; Shimizu, K.; Kondo, R. Fitoterapia 2010, 81, 120-123.

(9) Septama, A. W.; Panichayupakaranant, P. Pharm. Biol. 2015, 53, 1608-1613.

(10) Septama. A. W.; Panichayupakaranant, P. Pharm. Biol. 2016, 54, 686-691.

(11) Sato, M.; Fujiwara, S.; Tsuchiya, H.; Fujii, T.; Iinuma, M.; Tosa, H.; Ohkawa, Y. J. Ethnopharmacol. 1996, 54, 171-176.

(12) Septama, A. W.; Jantan, I.; Panichayupakaranant, P. J. Pharm. Pharmacol. 2018, 70, 1242-1252.

(13) Ko, F. N.; Cheng, Z. J.; Lin, C. N.; Teng, C. M. Free Radic. Biol. Med. 1998, 25, 160-168.

(14) Zheng, Z. P.; Chen, S.; Wang, S.; Cheng, K. W.; Wu, J. J.; Yang, D.; Wang, M. J. Agric. Food Chem. 2009, 57, 6649-6655.

(15) Oladimenji, P.; Cui, H.; Zhang, C.; Chen, T. Expert Opin. Drug Metab. Toxicol. 2016, 12, 997-1010.

(16) Li, P.; Yang, S.; Dou, M.; Chen, Y.; Zhang, J.; Zhao, X. J. Cancer Res. Clin. Oncol. 2014, 140, 2065-2075.

(17) Zhang, Z.; Guo, S.; Liu, X.; Gao, X. Drug Res. 2015, 65, 214-218.

(18) Goh, S. H.; Mohamed Alitheen, N. B.; Md Yussoff, F.; Yap, S. K., Loh, S. P. Pharmacogn. Mag. 2014, 10, 1-8.

(19) Arung, E. T.; Wicaksono, B. D.; Handoko, Y. A.; Kusuma, I. W.; Shimizu, K.; Yulia, D.; Sandra, F. J. Nat. Med. 2010, 64, 423-429.

(20) Tsai, M. H.; Liu, J. F.; Chiang, Y. C.; Hu, S. C.; Hsu, L. F.; Lin, Y. C.; Lin, Z. C.; Lee, H. C.; Chen, M. C.; Huang, C. L.; Lee, C. W. Oncotarget 2017, 8, 28342-28358.

(21) Chan, E. W. C.; Wong, S. K.; Tangah, J.; Chan, H. T. Sys. Rev. Pharm. 2018, 9, 58-63.

(22) Amable, L. Pharmacol. Res. 2016, 106, 27-36.

(23) Yang, Y.; Zhang, Z.; Li, S.; Ye, X.; Li, X.; He, K. Fitoterapia 2014, 92, 133-147.

(24) Solomon, M.; Wofford, J.; Johnson, C.; Regan, D.; Creer, M. H. Transfusion 2010, 50, 820-830.

(25) Chan, L. L.; Wilkinson, A. R.; Paradis, B. D.; Lai, N. J. Fluoresc. 2012, 22, 1301-1311.

(26) Chan, L. L.; Laverty, D. J.; Smith, T.; Nejad, P.; Hei, H.; Gandhi, R.; Kuksin, D.; Qiu, J. J. Immunol. Methods 2013, 388, 25-32.

(27) Chan, L. L.; Kuksin, D.; Laverty, D. J.; Saldi, S.; Qiu, J. Cytotechnology. 2015, 67, 461-473.

(28) Stankovic, M. S.; Curcic, M. G.; Zizic, J. B.; Topuzovic, M. D.; Solujic, S. R.; Markovic, S. D. Int. J. Mol. Sci. 2011, 12, 4190-4205.

(29) Alabsi, A. M.; Ali, R.; Ali, A. M.; Al-Dubai, S. A.; Harun, H.; Abu Kasim, N. H.; Alsalahi, A. Asian Pac. J. Cancer Prev. 2012, 13, 51315136.

(30) Li, C. J.; Chu. C. Y.; Huang, L. H.; Wang, M. H.; Sheu, L. F.; Yeh, J. I.; Hsu, H. Y. Cancer Lett. 2012, 319, 203-213.

Received May 24, 2019 Revised September 11, 2019 Accepted September 18, 2019 